\title{
Are there just two people in a dyad? \\ Dyadic configurations in multiparty family conversations
}

\section{Clotilde Pontecorvo, Sabine Pirchio and Laura Sterponi}

Dyadic interaction does not necessarily imply that just two people are present. It is often possible to single out episodes of dyadic interaction in multiparty contexts that we analyse, such as family dinner table conversation. Within such a speech event, multiparty participation framework (variously organized) is the default conversational structure. Consequently, a groundwork (Goffman, 1979) is required for participants to gain space and exclusivity for a dyadic exchange. This paper shows how dyadic framework is made out of the multiparty default interactional structure of a family dinner. Furthermore, we analyze the resources participants deploy to protect the dyadic exchange from anothers intrusion and/or from the risk of desertion of one member of the dyad. Young and older children actively participate in that activity and learn to manage it through diverse dyadic settings. It is not the number of participants that unequivocally determines whether an interaction is dyadic or multiparty. Varying and complex participation frameworks, alliances, and challenges are built and transformed within family dinner conversation; it is in their locus of the interactive organization of ongoing activity in which children are socialized to a complex socio-cognitive activity.

\section{Introduction}

The study of talk-in-interaction, at its onset, was committed to a dyadic model: Two individuals only are engaged; at any moment one will be speaking and the other will be listening; over the course of interaction the floor will be passed back and forth, namely the roles of speaker and hearer will be interchanged.

However, when social scientists began to be concerned with the analysis of actual conversational encounters, the inadequacies of the dyadic paradigm soon emerged: it became immediately apparent that the two-person arrangement is not the only form of verbal interaction, and perhaps it is not the most common either. Furthermore, the traditional categories of Speaker and Hearer appeared to be too gross and they obscured important distinctions of participation statuses and production formats. 
The dyadic paradigm began to be questioned in the early 70's with Dell Hymes's theorization and Erving Goffman's work. Within the SPEAKING model, articulated by Hymes for the study of speech events across communities in the world (Hymes, 1972b), the category of participants was divided into four components (vs. the traditional dichotomy speaker-hearer, source-destination, sender-receiver, addresser-addressee): 1) Speaker or sender; 2) Addresser; 3) Hearer, or receiver, or audience; 4) Addressee. Furthermore, Hymes showed how a wide range of different participant relations is enacted across different speech communities (Hymes, 1974).

Erving Goffman drew from Hymes's distinction among different types of participants and elaborated it more in detail. Goffman broke up the notions of speaker and hearer into more differentiated constituents, i.e. the production format and the participation framework (Goffman, 1979). In the delivery of any stretch of talk three different dimensions are at stake, hence three different roles are laminated: 1) The physical production of the utterances, performed by the Animator, namely the sounding box, «a body engaged in acoustic activity» (Goffman, 1979, p. 17). 2) The selection of the sentiments that are being expressed and the words, which encode those sentiments, carried out by the Author. 3) The positioning of a person or institution, i.e. the Principal, that message encompasses.

It follows that different production formats may characterize the talk being uttered.

On the side of the hearer, Goffman introduced various subtle distinctions, starting from the observation that among the people who in any given circumstance may hear what is being said, just some (a few of them or only one) are entitled and expected to participate in the speech event being launched or already in progress. Therefore, the first distinction to be made is between ratified and unratified participants. Naturally, ratified participants might not listen despite their official engagement in the encounter and the expectations of the speakers. On the other hand, there might be unratified participants who, though are denied access to the encounter, keep track of the talk being produced. Among these latter Goffman distinguishes overhearers, i.e. those who have unintentionally and inadvertently followed the talk, and eavesdroppers, i.e. those who have purposely and surreptitiously pursued it. Also the category of ratified participants is further decomposed: it may be possible to distinguish a primary recipient from the audience.

The meticulous distinctions introduced by Goffman, far from being useless products of a pedant analysis, brought to light the multiple roles being laminated in any stretch of talk, allowing researchers to begin to understand the complexity of everyday encounters. In conclusion, it is now evident, as Hymes (1974) has contended, that "the common dyadic model of speaker-hearer specifies sometimes too many, sometimes too few, sometimes the wrong participants» (p. 54). 


\section{Deconstructing the dyad}

Hymes's words, and the general criticism of the dyadic model we have sketched above, question the complexity of conversational encounters and the multiplicity of roles encompassed in the notion of participants. Consequently we are forced to reconsider dyadic interaction and try to unveil the manifold types of participation framework which may inform it.

Dyadic interaction is commonly defined as an exchange between two participants. However, the first observation one might want to make is that a conversational exchange between two individuals does not necessarily imply that just two people are present. Drawing from Goffman's theorization, one might point out that the presence of adventitious participants is rather frequent during stretches of dyadic interaction. Either as eavesdroppers or as overhearers, these non ratified participants cannot be ignored. They may not be listening to the ongoing conversation. However, often they do listen and then they either try to access to the exchange, thereby claiming a position of ratified participants, or they do so by being bystanders, namely they maintain their position of non ratified participants by politely avoiding any opportunity for intervening, and sometimes even by minimizing their actual accessibility to the talk. Therefore, in a multiparty setting a two-person interaction is possible not only because of the agreement and the actual engagement of the two interactants but also because of the active uptake of the status of bystanders by the others present.

In a multiparty context episodes of dyadic exchange may assume other different participation frameworks, starting from the fact that the participants are not always treated, and/or do not always act, as separate individuals (Lerner, 1993). Speakers may select more than one recipient and address them as an association and/or, speakers may cast themselves as members of an association. It is plain that in such cases the adjective dyadic refers to the parties, and not to the number of separate individuals participating. In other words, besides the two-person configuration, a dyadic interaction may involve a multi-person unit interacting with a separate individual or two collectivities talking to each other.

These different kinds of dyadic participation frameworks make relevant different types of actions, sequential patterns and the organization of turn-taking (Schegloff, 1991, 1995). For instance, by addressing a first pair part of any sort to multiple recipients as a collective unit conjoined participation is made relevant. Addressees may ratify the projected participation framework either by producing jointly the second pair part or by speaking singularly but as representatives for the association they are members of. On the other hand, to cast oneself as a member of a collectivity of co-present participants can solicit other members of the same social unit to co-participate by joining the achievement of the activity in progress. 


\section{Participation frameworks, communicative compe- tence and language socialization}

Such a perspective on conversational interaction, which analyzes how roles and voices are laminated within every verbal contribution - thereby also taking into account the dynamics of discursive positioning - has remarkable developmental implications.

On the one hand, it suggests a characterization of the notion of communicative competence (Hymes, 1972a) in which the skillful management of the structure of participation is a central aspect. In fact, the participation framework of conversational encounters is not rigidly determined by the number of participants. The establishment of any participation framework requires a shared agreement and a co-ordinated engagement of all the people who are present. Different kinds of participation framework imply, and are informed by, different linguistic actions, turn-taking formats, and sequential patterns. Moreover, the participation framework is not a fixed structure but it often changes in the unfolding of social interaction: participants continuously negotiate their involvement and position in the ongoing speech activity, thereby dynamically changing the underlying organization of participation. Therefore, communicative competence includes the ability to actively contribute to the dynamic structuring of participation in social interaction. This means mastering the semiotic (both verbal and non-verbal) resources for positioning oneself and the others into different participation frameworks and for operating changes in these configurations of interaction.

On the other hand, the analysis of the organization of participation in adultchild interaction may offer helpful insights into the process of socialization: for instance, what are the positions that the novices take - and/or are assigned to in different educational activities, at different stages of apprenticeship and how these different positionings affect the process of learning and are affected by it. Recent interdisciplinary research on situated learning and socialization (cf. Cole, 1985; Lave and Wenger, 1991; Ochs, 1988; Rogoff, and Lave 1984; Schieffelin and Ochs, 1986) for example, has revealed that different positions and different forms of participation ${ }^{1}$ are assigned/granted to young novices in different cultures, educative contexts, learning stages.

Along this stream of research, our study explores how parent(s)-child(ren) conversational interaction is structured during family dinners. In particular, our attention is focussed on dyadic episodes, on how they are interactionally set up within a default multiparty asymmetrical setting, what kind of participation they imply, what positions and discursive roles children assume within them. In other words, we are interested in the making, negotiating and changing of the structure of participation in order to meet the need of a dyadic exchange and in describing the semiotic resources employed for achieving this goal. 


\section{Methodological approach of the study}

Our research group has been studying language socialization in family dinner conversations for almost a decade now (Fasulo and Pontecorvo, 1994; Pirchio and Pontecorvo, 1997; Pontecorvo and Sterponi, 1997; Pontecorvo, Fasulo, Sterponi, in press; Sterponi and Pontecorvo, 1996).

The notion of language socialization refers to the process whereby children are socialized both through language and to the use of language (Schieffelin and Ochs, 1986). According to Schieffelin and Ochs «the process of acquiring language is deeply affected by the process of becoming a competent member of society. The process of becoming a competent member of society is realized to a large extent through language, by acquiring knowledge of its function, social distribution, and interpretations in and across socially defined situations.» (Schieffelin and Ochs, 1986, 167-168). The language socialization approach considers conversational discourse the major medium for conveying sociocultural knowledge and the most powerful tool of socialization. The socializing potential of language lies not only in its symbolic content but in the whole choreography of language (Ochs, 1991). Therefore, this perspective advocates examining closely everyday verbal interaction and taking into account not only the semantic content of discourse but also all its other various formal and functional dimensions (e.g. participation frameworks, morphosyntactic constructions, phonological features and sequential organization). For this reason, in exploring a number of different aspects of language socialization in family dinner conversation we have adopted some Conversation Analysis procedures (Sacks, Schegloff and Jefferson, 1974; Sacks, 1992).

The present study is based on a collection of 30 videotaped and fully transcribed dinner conversations of 10 middle class Italian families, each including two parents, at least one child between 3 and 6 years of age, and an older sibling. Transcriptions were revised by two judges both for verbal and non-verbal activity.

Family dinner can be considered as a collective social activity within which multiparty participation framework (variously organized) inform the default conversational structure. That is to say, all the members of the family who are at dinner are ratified participants of such a social activity. However, several episodes of dyadic interaction occur in almost all the family dinners of our corpus of data. These sequences represent departures from the default organization of participation so they imply a range of practices for transforming and reorganizing the structure of ongoing interaction. In observance of the Conversational Analysis approach, each of us independently selected a large collection of examples of dyadic conversational sequences. The perspective of participants and the semiotic moves used for structuring dyadic exchanges were used as common selection criteria. The sequences we all agreed upon, as being dyadic exchanges, were used as the corpus for our subsequent analysis. 
In what follows we document different ways a dyadic framework is made out of the multiparty interactional structure of family dinner. In particular, we single out and analyze the framing operations participants (ratified and not ratified; speakers and hearers) perform to collaboratively structure different kinds of dyadic participation arrangements in.

Not only talk but also body posture and gaze are employed to signal participants involvement in (or detachment from) the activity in progress. In launching a sequence of dyadic two-person interaction, participants often perform spatial and orientational maneuvers as a means for gaining the space and exclusivity for a dyadic exchange. On the other hand, when collectivities are engaged in episodes of dyadic interaction mutual agreement is stipulated and sustained by the use of various linguistic devices (e.g. the use of plural pronouns, collective names, etc.).

In describing the different dyadic configurations we found in our data - and the resources participants employed to set up these different participation frameworks - we will start from the arrangements within which all or the majority of the family members are engaged, and then we will proceed to examine more exclusive dyadic participation frameworks.

However, we would like to begin by illustrating a sequence which is in no way structurally dyadic but has the dyadic participant arrangement as the object of talk, discussion and negotiation:

Revealing a secret: dismantling and deligitimizing exclusive dyadic interaction

\section{Excerpt 1}

Minelli Family. Dinner 1

Participants: Sara (mum), Matteo (dad), Luisa (3.10 year-old) Ugo (10.9 yearold).

\section{((Ugo whispers something in Mum's ear ))}

1.Luisa: l'ho sentito ((ad alta voce)).

I heard that ((loud))

((Dad coughs while continuing to move the dishes))

2.Ugo: $\quad$ NO? ((a mum)) e come fai? ((a Luisa))

no? ((to Mum)) and how could you hear? ((to Luisa))

3.Mum: che hai sentito? ((a Luisa)) what did you hear ((to Luisa))?

4.Luisa: una cosa che mi ha, ((con voce acuta)) something that ((with a high pitch))

5.Mum: e che cosa mi ha detto ((imitando la voce di Luisa))? And what did he tell me ((imitating Luisa's voice))?

6.Luisa: tha detto domani vai a ufficio ((scandendo le parole)). He told you tomorrow you go to the office ((emphasizing each word)) 
7.Ugo: $\quad$ ((sorride a mum in modo complice)). no no no toppato proprio toppato.

No no no that's wrong just wrong ((he looks at Mum smiling like an accomplice))

((Mum addresses herself to Luisa))

8.Luisa: no Ugo di:m[mela:].

No Ugo tell me

9.Mum: [mangiati] la verdura U'.

Eat your vegetables U'

10.Ugo: [ [(he nods to Mum $))$ ]

11.Luisa: [dimmi] - [dimmi la cosa].

Tell me tell me it

12.Mum: [tagliala].

Cut it

13.Luisa: [che gli hai detto:].

That you told her

14.Mum: [così ti viene meglio a metterla in bocca].

So, it's easier for you to get it in your mouth

15.Ugo: [sì me] la stavo tagliando. ((a mum))

yes I was cutting it ((to Mum))

no è un segreto. [non mi va di dirtelo]. ((a Luisa))

no it's a secret I don't want to tell you ((to Luisa))

16.Luisa: [no di] - dimmelo: ((in tono spazientito)).

No tell me ((in an impatient tone))

17.Ugo: no!

18.Luisa: dimmelo.

Tell me

19.Ugo: $\quad$ e io non te lo dico.

Well I don't want to tell you

20.Luisa: mamma che ti ha detto? ((alzandosi in ginocchio sulla sedia avvicinandosi così alla mum))

Mum what did he tell you ((on her knees on the seat, in order to get closer to Mum))

21.Mum: ( ) ((whispering something in Luisa's ear))

22.Luisa: l'ho sapu:to! ((contenta rivolgendosi a Ugo. Si siede sulla sedia))

$[\ldots]$

I knew it ((she is happy and addresses Ugo. She sits on her seat))

Excerpt 1 reveals the participants' perspective on exclusive dyadic interactions in family dinner conversation: Luisa complains about the exclusive exchange her mother and Ugo are entertaining and claims the right to participate (at least as a hearer). Luisa's intrusion gives rise to a playful triadic sequence in which the girl tries to figure out what Ugo was whispering in his mother's ear. Initially Luisa meets with Ugo's explicit resistance and mother's reluctance but eventually she has the secret revealed! Exclusive dyadic interactions, like the one just presented in excerpt 1, are often challenged, thereby bringing about a change in the participation framework. The emerging multiparty sequences are often lively discussions in which discursive roles and participants' status are negotiated and the exclusive dyadic framework is dismantled and deligitimized. 


\section{Multiparty dyadic configurations}

In this paragraph we want to illustrate participation arrangements in which participants are aligned in two teams. No one is potentially excluded from participating in the exchange and more than two family members can actually be interacting insofar as they side with either team.

\section{Exerpt 2}

Fanaro Family. Dinner 1

Participants: Teresa (mum), Silvano (dad), Stefania (5.5 year-old) Sergio (7.5 year-old).

((Sergio is taking the wrapping off his Easter egg and is looking for the surprise inside, but he cannot open it; Dad succeeds in opening the suprise and everyone is looking at it))

1. Sergio: [bello].

Nice

2. Stefania: [ti piace] ((intendendo la sorpresa rivolta a Sergio))?

Do you like it ((she addresses Sergio))?

3. Mum: ci sono tutti i fiorellini qua guarda [Ste'] ((riferendosi alla casetta di Stefania))

there are all the little flowers here look Ste' ((about Stefania's little house))

((Stefania puts her finger in her mouth and looks at Sergio))

4. Sergio: [mamma che] non è quello uguale.

Mum isn't it the same

5. Mum: Titti si mette a riposare proprio qua.

Tweety comes to rest just here

6. Sergio: non è uguale [a quello di Stefania] ((con atteggiamento soddisfatto)).

7. Mum: [cos'è quello]?

What is that?

8. Sergio: vediamo. ((aprendolo))

let's see ((he is opening it))

9. Stefa.: $\quad$ e che è? ((alzandosi in piedi e avvicinandosi a Sergio)) and what is it ((she gets up and she gets closer to Sergio))

10. Sergio: UN AEREOPLANO ((in tono concitato)) .

11. Dad: An airplane ((in an exited way))

Wow how lucky you are it's exactly the one that

12. Mum: [ammazza che bello].

Wow it's great

13. Dad: proprio quello che ti piaceva a te.

Exactly the one you wanted

14. Sergio: [BELLO UN AEREOPLANO].

15. Dad: $\quad$ Great an airplane
[un aereoplano]. ((prendendo le istruzioni))

an airplane ((he picks up the instructions))

16. Sergio: papi senza le istruzioni che ce vole a montallo.

Daddy, without instructions. It's easy to put it together 
17. Stefa.: a me me [piace de più la casa].

I I like the house more
1questo è proprio bello guarda]. ((guardando il foglietto delle istruzioni))

this is really nice look ((he looks at the instruction sheet))

19. Mum: famme un po' vede'. ((rivolta a dad))

let me see ((she addresses Dad))

20. Sergio: guarda che aereoplano ma'. ((prende il foglietto illustrativo lo alza per farlo vedere a mum e poi il dad se lo riprende))

look what an airplane mum ((he takes up the instruction sheet and he gets up to show it to Mum; then Dad takes it up again))

21. Mum: comunque guarda che Kinde:r - quello i Kinde:r - questi uovi Kinder (so' proprio) una bella sorpresa.

Anyway see the Kinder that- the Kinder, these Kinder eggs really have a great surprise

22. Stefa.: non so' ovetti Kinder.

They are not Kinder eggs

23. Mum: eh sono sempre gli uovi della Kinder questi Stefania.

Well these are still eggs from Kinder Stefania

24. Stefa.: dai giochiamo ((parla a mum con un dito in bocca e in tono lamentoso)).

Come on let's play ((she talks to Mum in a complaining way with a finger in her mouth))

25. Mum: guarda Titti si mette a riposare qui [sulla poltroncina un attimino eh]?

Look Tweety gets to rest here on the little chair for a little while

26. Sergio: [bello (.) papi].

Nice daddy

((Stefa. turns herself toward Sergio))

27. Sergio: questo senza che [me dici].

This without saying to me

28. Mum: [e controlla la situazione]. ((tenendo in mano un pupazzetto))

[and controls the situation] ((Holding the toy in her hands))

29. Sergio: come lo deve [montare].

How does he have to put it together

30. Mum: [dove] se n'è andato gatto Silvestro. adesso sai che gli combino quasi quasi. guarda che gli faccio $\mathrm{mhmm}$.

Where did Silvester go. Now do you know what I'll do to him just look what $[\ldots]$ I'm going to do to him

Excerpt 2 illustrates a conversational schism: the four family members are all concurrently interacting but not in a joint conversation. They are divided into two dyads, engaged into two separate conversations (though on parallel topics). At the beginning of the sequence, Sergio is trying to draw the others' attention to the toy he has just taken from the chocolate egg. While the father and Stefania follow Sergio's actions the mother does not; instead she tries to engage her daughter in a parallel, though separate, conversation/activity (lines 3 and 5). Sergio initially contrasts and resists these diverting moves (cf. lines 4 and 6) by addressing the mother explicitly, thereby attempting to captivate her attention too but without success. Eventually Stefania responds to the mother's invitation to engage in a separate playful activity. A schism is now cast and two parallel dyadic 
interactions unfold for several minutes. Though this participation arrangement initially met Sergio's resistance and required a few attempts by the mother to have Stefania included in the playful interaction with her, once it is delineated and gets all the participants ratification it is maintained for a good part of the family dinner. We would argue that such long lasting detours from multiparty exchanges occur insofar as they do not exclude anyone from engaging in meaningful interactions.

Even when just two participants actually converse the dyadic interaction may not be necessarily exclusive: We found in our data episodes in which the two interlocutors speak as member of a party, thereby indirectly involving the other members of the family in the ongoing conversation. Parental alignment is frequently evoked and contrasted with the children's front. However, cross-generation alliances also sometimes occur. The following two excerpts show respectively these collective dyadic configurations:

\section{Excerpt 3}

Minelli family, dinner 3

Participants: Sara (mum), Matteo (dad), Luisa (3.10 year-old ) Ugo (10.9 yearold).

((Ugo has just tried to serve himself the water from the bottle by handling it with one finger. The bottle risks falling on the table. Both the parents scold Ugo severely))
1. Ugo:
no. [che cosa ho fatto]?
2. Mum: [non lo sai]?
no. What did I do?

you don't know?

va be' la prossima volta te lo facciamo (.) capire meglio con uno schiaffone.

ok the next time we'll make you understand it better with a big slap.

$\mathrm{mhm}$ ? visto che non l'hai capito così.

3. Dad: $\quad$ visto che continui a fare lo stupido.

as you continue to act stupidly.

4. Luisa: $\quad{ }^{\circ}$ h. (1.5) ${ }^{\circ} \mathrm{h}$ guarda. non si f - non $s-$ non si ri -

look you don't do- you don't- you don't re-

non si dice così al fratellino. io me l'ha spiegato la nonna. ((a dad))

don't talk like that to my clear brother. grandma explained it to me ((sighing excitedly to dad))

5. Mum: il fratellino perché ci fa disperare.

Your clear brother because he drives us to despair.

versa l'acqua c- con un dito facendo così. ((imita l'azione di Ugo))

He pours out the water with one finger. ((she imitates Ugo's action))

6. Luisa: non è vero. adesso glielo spiego io:.

It's not true. now let me explain it to him.

7. Mum: eh spiegaglielo.

eh explain to him

8. Luisa: Ugo così non si fa perchè la bottiglia se la versi con un dito=non si fa

Ugo you don't do it like that because if you pour it out of the bottle with one 


\section{finger you can't do it}

perchè si può cadere il bicchiere con tutta la bottiglia. capito?

because the glass and the bottle will tip over. Do you understand?

9. Ugo: ((vertical headshakes))

In scolding Ugo for his misbehavior the mother uses the first person plural, thereby appealing to her husband and casting herself as spokesperson of the parental couple. This alliance is ratified by the father, who actually co-constructs the reproach by appending a severe negative assessment to Mum's opening threat. It is worth noting that the father's contribution is syntactically linked with the mother's preceding turn and syntactically mirrors it. On the other side the children's front is not jointly constructed: it is only Luisa who invokes the alignment with her brother (line 4), speaking in defense of him, while Ugo remains silent. Nevertheless, Luisa's complaint is responded to by the mother and the clashing of the two fronts clearly emerges.

\section{Excerpt 4}

Minelli Family. Dinner 6

Participants: Sara (mum), Matteo (dad), Luisa (3.10 year-old) Ugo (10.9 yearold).

((While speaking about her favorite TV show Luisa offends her brother. She claims that Ugo is not smart as he does not watch the show. Mum intervenes reproaching Luisa for her rudeness. Then Dad takes Luisa's side))

1. Dad: l'albero Azzurro è una: - una trasmissione veramente.

The Blue Tree is really a- a show

che apre il cervello. diglielo. è così? ((a Luisa))

which opens up the mind. Tell him. Isn't it? ((to Luisa))

e quando noi la vediamo Ugo non c'è mai.

and when we watch it Ugo is never there.

per questo la bambina ha voluto sottolineare questa cosa qua.

This is why my little girl was pointing this out

2. Mum: ma noi non la possiamo sapere tutto questo discorso ((tono scocciato)).

But we cannot know all about this.

io capisco questo. anche [Ugo] capisce questo.

I understand this and Ugo understands this too

3. Ugo: [((laughs))].

4. Mum: scusami sai.

\section{Excuse me you know}

5. Dad: perchè lei,

Because she

6. Luisa: ((groaning)).

7. Dad: è più piccola. e ha più tempo per vedere queste cose.

Is younger and she has more time to watch these things

8. Ugo: no io dico. (.) magari [fossi] io piccolo!

No I say how great it would be if I were little

9. Dad: [è vero]? [eh]? ((a Luisa toccandole la fronte))

that's right ((to Luisa)) isn't it ((while touching Luisa's forehead))? 
10. Mum: [e] di che cosa parla questa trasmissione? ((a Luisa))

and what is this show about ((to Luisa))

11. Dad: di come si costruiscono giochi: storie: ((con tono da elencazione)).

About how to make toys, stories,

è vero? ((rivolto a Luisa)) mhm? poi? binocoli.

(...)

Is that right? ((to Luisa)) $\mathrm{mhm}$, then, binoculars

In this excerpt the cross-generation alliances between Ugo and the mother, Luisa and the father are cast by the parents through the use of the first person plural pronoun and third-personalizing segments of talk. Third-personalizing involves the representing of the experience of a protagonist who is present but who is neither speaker nor addressee being questioned about experience (Taylor, 1995). Through this discursive device the parents position Luisa and Ugo on opposite fronts in an open dispute. They articulate and voice the reasons of the two sides and then attempt to reach reconcilement.

\section{Topics of conversation and participation frameworks}

In family dinner conversations, as in many other contexts (e.g. the classroom), different activities are closely associated with certain participants, hence with particular participation frameworks ${ }^{2}$. For example, feeding usually involves only the mother - young child dyad. Furthermore, there are topics of talk, which are typically introduced by certain family members and specifically addressed to some others. Topics, such as work issues, domestic economy, household duties, belong to the parents and usually children are excluded from their discursive unfolding:

\section{Excerpt 5}

\section{Fanaro Family, Dinner 3}

Participants: Teresa (mum), Silvano (dad), Stefania (5.5 year-old) Sergio (7.5 year-old).

1. Mum: è troppa la - il lavoro che si svolge lì dentro. lì c'è una confusione ( ).

2. Dad: le professioni sanitarie secondo me so' quel The health professions in my view are the onessono (.) le professioni fra le - quelle più stressanti che possono esistere. are the most stressful professions that ever existed

3. Mum: ma che scherzi? You're so right (...)

4. Dad: solo che non lo riconoscono che è 'na professione stres- stressante. Yet they don't acknowledge that it's a stressful profession 
e questo è il punto.

and this is the point

5. Mum: no oggi ho detto.

No today I said

6. Dad: comunque da uno studio fatto [me sa].

Anyway from a study done I think

((the parents keep on talking about health professions and Stefania eventually leaves the table))

7. Dad: Stefania però a me non me piace quando fai così.

Stefania I don't like it when you do that.

stai insieme a noi a tavola. è vero che stiamo parlando noi.

Stay with us at the table. It's true that we are talking

però una volta tanto concedeteci un minuto ((rivolto a Stefania))

however at least once in a while give us a minute ((to Stefania))

per parlare fra me - con - io e mamma no.

For us to speak, me and Mummy. no

((Stefania takes a cup and drinks))

8. Dad: una volta [tanto] dico eh.

Once in a while I mean eh

9. Mum: [perchè] (.) oggi non ci siamo visti per niente.

Since today we didn't see each other at all ((to Sergio))

10. Sergio: infatti io vi sto lasciando parlare. ((rivolto al dad))

as a matter of fact I'm leaving you talk.

se - soltanto che quando dicete qualcosa che io conosco

If - only when you say something that I know about

11. Dad: dite. non dicete. ((Dad corrects a linguistic mistake Sergio just made))

12. Sergio: quando dite qualcosa che io conosco faccio una battuta.

When you say something that I know clear I say something funny

così per farvi ridere.

just to make you laugh

In this excerpt the parents, who are involved in a long exchange about their profession and what happened at work, claim the right to entertain a dyadic interaction during the family dinner. However, when faced with Stefania's attempt to leave the table the parents apologize and justify the fact that they are excluding and neglecting their children from conversation. Furthermore, they beg their children's permission to continue to talk about their work. In other words, the parents' excuses, justifications and their request for permission reveal that they consider the dyadic exclusive conversation as a dispreferred activity within the context of family dinners. While Stefania tries to break this participation framework through leaving the table, Sergio adopts a different strategy of resistance by entering into the parents' conversation whenever he can. In conclusion, it is worth noting that Sergio's interventions though disruptive of the dyadic framework sustained by the parents are devoted to amusing his parents and are not attempts to change the subject of the ongoing conversation. 


\section{Threatening the dyad}

In this paragraph we analyze other episodes in which an ongoing dyadic interaction is challenged by other participants at the dinner table.

\section{Excerpt 6}

Minelli family. Dinner 1

Participants: Sara (mum), Matteo (dad), Luisa (3.10 year-old) Ugo (10.9 yearold).

((Mum is feeding Luisa. The child is singing happily))

1. Ugo: ma che dice?

but what is she saying ((to Mum))

2. Mum: niente è contenta. ((preparando un boccone per Luisa)) è probabile.

3. Ugo: $\quad$ io [so' stanco] ((a bassa voce))

$$
\text { nothing she's happy it's likely ((she is preparing a spoonful of food for Luisa)) }
$$

\section{I'm tired ((in a low voice))}

4. Luisa: [ [(emette a bocca chiusa dei suoni di apprezzamento del cibo))].

((She sounds an appreciation for the food))

5. Mum: [sei stanco]? ((a Ugo girando la testa verso di lui))

are you tired? ((looking toward Ugo))

6. Ugo: ((nods))

7. Mum: perché?

$\begin{array}{ll}\text { 8. Ugo: } & \text { why? } \\ \text { [n:: 'o so]. }\end{array}$

\section{I don't know}

8. Mum: [che hai fatto] che sei stanco?

10. Ugo: boh [non lo so].

\section{I don't know}

11. Mum: oggi a scuola che hai mangiato? ((a Ugo rivolgendosi verso Luisa tentando di imboccarla))

what did you eat today at school ((to Ugo while trying to feed Luisa))

12. Luisa: mamma guarda.

Mum look

13. Luisa: $\quad{ }^{\circ}$ sai [che Akela]

do you know that Akela

14. Mum: ((As soon as she has given Luisa the food the mother turns to Ugo))

15. Ugo: [mhm oggi] ho mangiato fettine ((a mum))

well today I ate steak ((to Mum))

16. Mum: tieni [il pane]. ((a Ugo, prendendo un pezzetto di pane e avvicinandolo a lui)).

Take this bread ((handing a slice of bread
17. Luisa: $\quad$ [sai, che ho fatto] una cosa [con Akela]?

Do you know that I did something with Akela

18. Ugo: +, [e::] [riso].

And rice 
19. Mum: [scusa] sto chiedendo prima una cosa a Ugo. ((a Luisa. Si rivolge verso Ugo)) excuse me I'm asking Ugo something ((to Luisa, then turns to Ugo))

20. Ugo: e riso.

And rice

((Mum turns to Luisa to feed her ))

In this excerpt Ugo and the mother are talking to each other. At the same time the mother is also involved in feeding Luisa. Therefore, it might be claimed that two dyadic interactions (verbal interaction with Ugo and non-verbal interaction with Luisa) are concurrently ongoing, with the mother being engaged in both. The mother keeps the two interactions separate by clearly marking changes in her body orientation according to the child she wants to interact with at any single moment (cf. line 5). However, just when the mother is turned toward Luisa to feed her, the girl starts talking. Luisa's interventions begin with pre-requests that on the one hand aim at capturing the mother's attention and on the other hand function as mitigation of the disruptive insertions into the ongoing conversation between Ugo and the mother. Luisa's intervention meets the mother's refusal and reproach: the girl cannot interrupt an ongoing conversation and has to wait for its end in order to have the floor for her telling.

However, topic coherence does not always guarantee the possibility of intervention and acceptance within an ongoing dyadic interaction. In the following excerpt Mario repeatedly attempts to participate in the mother's report but his interventions are refused even though they are clearly on-topic and, moreover, about an episode which has Mario as protagonist.

\section{Excerpt 7}

Tanucci Family. Dinner 4

Participants: Paola (mum), Fabrizio (dad), Leonardo (3.9 year-old) Mario (10.6 year-old).

1. Mum: senti. ((rivolta a dad con in mano un'insalatiera)) te volevo dire no?

Listen ((to Dad holding the salad bowl in her hand)) I just wanted to tell you, you know?

a parte il fatto che prima vabbè la riunio::ne

Besides the fact that before well the meeting.

fattela dire da Mario ((ridendo)) [perchè guarda] ((cambiando tono)) .

Let Mario tell you about it ((laughing)) because look

2. Leonardo: [chi me l' ha toto] quello [ro:sa::] ((con tono lagnoso))?

Who took away the pink one ((in a moaning tone))

3. Mario: [te] volevo di' solo 'na cosa ((a bassa voce rivolto a Dad $)$ ).

I just wanted to tell you one thing ((in a low voice to Dad))

4. Mum: [aspetta] ((rivolta a Leonardo)).

wait ((to Leonardo))

scusa un momento Mario. ((rivolta a Mario))

excuse me a moment Mario ((to Mario)) 
5. Leonardo: quello ro:sa:

6. Mum: eccolo quello rosa ((facendo un po' il verso a Leonardo)) teso:ro. ((indica con la mano vicino al piatto di Leonardo))

Here is the pink one ((mimicing Leonardo's voice))

7. Mario: ti dico solo ‘sta cosa. ((a dad))

I'll just tell you this ((to Dad))

8. Mum: aspetta un momento su! fammi finire il discorso. ((a Mario))

Wait a minute come on let me finish my point ((to Mario))

9. Mum: allora (.) [ascolta] eh. ((a dad))

So listen ok ((to Dad))

10. Dad: [eh]. ((a mum))

ok ((to Mum))

11. Mum: a parte eh dopo te la spiega Mario la riunione.

Besides well later Mario is going to tell you about the meeting

perchè è una cosa oscena. e poi dopo siamo andati

because it was awful. And then we went

((Dad takes the salad bowl Mum just put on the table))

12. Mum: ti voglio soltanto (.) e: dire un aspetto di Mario (.) no?

I just want you (.) well to know about something about Mario ((to Dad))

(1.5) ((Dad looks at Mum))

((The mother talks about what happened that afternoon: When she was talking to the manager of the Stadium, where she works as a running team trainer, Mario has entered the conversation and has asked the manager of the Stadium for a special card which would allow him to get into the Stadium. Mario's request was disregarding the mother's previous direction not to ask for the card as it was not necessary any more for Mario to get into the Stadium)).

13. Mum: non c'era bisogno che::: - di questa cosa.

It wasn't necessary that- this

((the phone rings and the mother is going to answer))

14. Mario: poi io gli ho detto ((scandisce le parole)) [anche per il] - [di quest'amico].

Then I told him as well for- about this friend

15. Leonardo: [vado io eh] ((al telefono)).

16. Mum: [vai tu]? va bene.

Will you go? Ok

((Leonardo scende dalla sedia))

17. Mum: corri.

run

18. Leonardo: ECCOMI! ((corre fuori dalla cucina)) .

19. Mum: $\quad\left[{ }^{\circ}\right.$ allora $\left.^{\circ}\right]$.

I'M COMING ((running out of the kitchen))

so

20. Mario: [poi gli ho detto] anche per questo amico.

Then I told him for this friend as well

21. Mum: eh allora senti. io però gliel'avevo data la spiegazione.

Then listen. I however had explained to him ((why he should not ask for the card))

lui $(($ Mario $))$ non si è arreso

$\mathrm{He}$ ((her son Mario)) didn't give in

ha trovato il sistema di inserirsi nel discorso e

He found a way to enter the conversation and 
chiederglielo lu- lui direttamente.

To ask him directly for it

cioè hai capito com' è tena:ce?

That is to say, do you understand how tenacious he is

com' è:::,

((Dad nods))

how he is:::

22. Mum: anche se magari ci posso essere rimasta male

even though let's say I could have been embarrassed

perché come mamma mi poteva anche:: (.) ascoltare,

((Dad nods))

because as his mother, he should listen to me

23. Mum: allora mentre da una parte ci so rimasta male,

so if on the one hand I was embarrassed

dall' altra per dirti. no?

on the other hand, to tell you

ha trovato un siste-

he found a syste-

((Leonardo calls his father who then goes to the phone))

While reporting to her husband about Mario's behavior the mother monitors and helps the little Leonardo. This forces her to stop the telling repeatedly and Mario avails himself of these interruptions to insert himself into the conversation and tries to give the father his own version of the episode being talked about. It might be noted that Mario's interventions not only occur when the mother is momentarily focused on the younger child but they are also mitigated by politeness markers (i.e. low volume and diminishing terms [«just a thing»]). Yet, these clever discursive expedients are not enough for Mario to be ratified as co-teller: the mother does not allow him to contribute to the report (lines 4 and 8). Furthermore, even when eventually Mario gets to say something about the episode being recounted, his intervention is utterly ignored both by the mother, who continues her telling, and by the father, who keeps his gaze on his wife (lines 14 and 20).

In conclusion, this excerpt shows how a dyadic framework can be maintained despite others' attempts to insert and open up the interaction. Specifically in this sequence the power of parents is evident in positioning the child both in the third-personalizing narrative and in the very same ongoing narrative activity.

\section{Children as interlocutors and the observance of participation's rules}

The excerpts illustrated so far have shown that in family dinner conversation the participation framework is not established once for all but, on the contrary it is continuously changed and negotiated. Therefore, in order to effectively participate in dinner conversations children have to be sensitive (i.e. recognize and con- 
form) to different structures of participation and to master the maneuvers for switching from one framework to another.

The last two excerpts we will present reveal that even young children are competent participants who not only observe the rules of participation but can also strategically use them to achieve specific personal aims (thereby also demonstrating a surprising metacommunicative and metapragmatic ability):

\section{Excerpt 8}

Tanucci family. Dinner 2

Participants: Paola (mum), Fabrizio (dad), Leonardo (3.9 year-old) Mario (10.6 year-old).

((Leonardo is involved in a dyadic interaction with his mother: he asks her what to write or draw, the mother provides an item and then Leonardo follows the mother's suggestion))

1. Leonardo: che devo scrive'?

what should I write ((to Mum, while grasping the pen))

2. Leonardo: che devo scrive'?

what should I write ((to Mum))

((The mother moves her head back and forth))

3. Dad: $\quad$ quello che vuoi Leo.

Whatever you want Leo

4. Leonardo: NO' LO STO DIZENDO A TE. [LO STO DIZENDO A MUM].

I'M NOT ASKING YOU I'M ASKING MUM

5. Mum: [((she nods looking toward Dad $))]$.

6.Dad: $\quad$ scusa. ((rivolto a Leonardo))

I'm sorry ((to Leonardo))

In this sequence the little Leonardo reproaches his father (line 4) for embezzling the floor of conversation and interfering with the ongoing dyadic interaction between he and his mother. Though uttered in a rather sharp, straightforward way (high volume and lexically redundant), Leonardo's blame is unobjectionable in its content. As a matter of fact, the mother ratifies it by nodding towards her husband, who then is forced to beg his pardon for violating a rule of participation.

We wonder whether Leonardo would have complained anyway about the interference in the ongoing dyadic interaction if answered by the father in a more satisfactory way. This is mere speculation and we cannot provide an answer. It is worth noting, however, that Leonardo not only demonstrates knowledge of rules of participation in conversation but he is also able to explicitly appeal to these rules to protect the interaction he is involved in from possible interference and/or interruption.

The following excerpt is illustrative of an opposite situation in which the 10year-old Ugo tries to recruit his father as primary recipient of his storytelling but meets the father's disattention: 


\section{Excerpt 9}

\section{Minelli Family. Dinner 5}

Participants: Sara (mum), Matteo (dad), Luisa (3.10 year-old) Ugo (10.9 yearold).

1. Ugo: un bambino,

A kid ((looking towards Dad))

((Luisa gets closer to Dad and whispers something in his ear))

2. Ugo: ha fatto così negli occhi di (.) ((facendo un segno con due dita in avanti))

Did this in the eyes of ((raising two fingers as a gestural illustration of the action being described))

un'altra bambina.

another girl

negli occhi pa::. ((facendo il segno di mettere le due dita negli occhi)).

in the eyes dad

((Luisa is standing near Ugo and listens to his storytelling))

3. Ugo: e poi negli occhi di <Bagheera> Manuela la nostra.

And then in Bagheera's eyes. Our Manuela.

4. Dad: vabbè.

well

5. Ugo: $\quad$ gli (ha) detto -

He said

io gli ho fatto solo così. ((alza il braccio allungando due dita))

(3.0)

I just did this ((raising his arm and pointing two fingers))

6. Luisa: al centro? [dentro] gli occhi.

7. Dad: $\quad[($ dentro $)]$.

8. Luisa: Right in

(3.0)

9. Luisa: dentro gli occhi?

Into her eyes

10. Ugo: ((ride guardando il dad)) io non lo capisco ((rivolto a mum))

((laughs looking towards Dad then turns towards Mum)) I don't understand him ((Dad))

io gli parlo e lui. ahm. divora. ((mima di addentare voracemente la pizza))

I'm talking to him and he, ahm, gobbles ((miming greedy eating))

11. Mum: ((laughs))

12. Dad: $\quad$ stavi parlando con me? ((rivolto a Ugo))

were you talking to me ((to Ugo))

13. Ugo: no stavo parlando con il muro.

14. Dad: stavi parlando con tutti noi.

You were talking to us all. 
Notwithstanding the fact that Ugo never explicitly selected his father as primary recipient he complains about his disattention. The father replies with a scapegoating move, pointing out that he was not the only addressee, therefore he was not totally in charge of the conversational work storytelling addressees have to perform (e.g. continuers, understanding markers, assessments [Schegloff, 1982]).

In effect, what Ugo is complaining about is the lack of the recipients' reaction/assessment of the problematic event he has been recounting (Goodwin and Goodwin, 1992). So, on the one hand Ugo does not seem to be able to make effective use of the semiotic resources to set up an exclusive participation framework (with the father as primary recipient), but on the other hand his complain reveals that he knows well the rules that participants to the storytelling activity have to follow and that he can appeal to these rules in order to negotiate the organization of participation in the ongoing activity.

\section{Conclusions and educational implications}

This work shows that within the context of family dinner, the structure of participation in conversation is far from being a rigid scheme with fixed positions. On the contrary, family members continuously negotiate their involvement and position in the ongoing speech activity, thereby dynamically changing the underlying participation framework. Special attention was devoted to the analysis of children's participation in family dinner conversation, particularly in terms of their contribution in the framing work being carried out. Children have been shown to master subtle linguistic and non linguistic strategies for positioning themselves into different participation frameworks and to operate changes in these configurations of interaction. We suggested that this ability is an important aspect of what to be a competent member of the speech community means.

Among the various participation configurations that inform our data, there are different dyadic arrangements. This work illustrates the ways in which within the default multiparty participation configuration of family dinner conversation - dyadic exchanges are framed, protected, challenged, and transformed. In particular, we aimed at showing how the dynamic framing of participants' positions in conversation is an interactional accomplishment. Specifically, a dyadic configuration operates only if participants align into two separate teams or if they take up the status of bystanders. In this sense, in order to account for a two-person dyadic interaction it is necessary to go beyond the dyad and also consider the other company present. These findings have remarkable educational relevance: in the school setting and in many other learning contexts (e.g. athletic training) the interaction between expert and novice is often structured dyadically but within multiparty contexts. Often the teacher addresses the students as a whole (i.e. the learners team); on other occasions the dyadic interac- 
tion is individualized (i.e. just the teacher and one student are directly involved) and the others participate as bystanders. It has been already pointed out that these different forms of dyadic participation framework make relevant different types of actions, sequential patterns and turn-taking organization, which in a turn can give a different characterization to the ongoing learning activity. Certainly, it would be worthwhile to analyze in more detail the relationship between forms of participation and instruction in different educational settings.

Furthermore, this work singles out and describes some of the semiotic resources participants employ in the making and unmaking of dyadic frameworks. In particular, our analysis has revealed that children actively and effectively pursue the space and the exclusivity for dyadic exchanges. As a matter of fact, adultchild interactions are extremely frequent in the context of family dinner. It would be interesting then to explore, as further paths of inquiry, whether and how the participation frameworks children are engaged in change across ages, namely whether and how, longitudinally, children move from mostly experiencing dyadic two-person exchanges towards being involved in larger, more complex and dynamic multiparty interactions.

\section{Notes}

1 Consider, for instance, the well known notion of legitimate peripheral participation (Lave and Wenger, 1991) and that of scaffolding (Wood, Bruner and Ross, 1976)

2 And reflexively these activities and structures of participation constitute the context (cf. Duranti and Goodwin, 1992).

\section{References}

Cole, M. (1985). The zone of proximal development: where culture and cognition create each other. In J. Wertsch (Ed.), Culture, communication and cognition: Vygotskian perspectives.(pp. 146-161). New york: Cambridge University Press.

Duranti, A. \& Goodwin, C. (1992) (Eds.). Rethinking Context: Language as an Interactive Phenomenon. Cambridge: Cambridge University Press.

Fasulo, A., \& Pontecorvo, C. (1994). «Si, ma questa volta abbiamo detto la verità». Le strategie argomentative dei bambini nelle dispute familiari. Rassegna di Psicologia, 3, 83-101.

Goffman, E. (1979). Frame Analysis: An Essay on the Organization of Experience. New York: Harper and Row.

Goodwin, C., \& Goodwin, M. H. (1992). Assessments and the Construction of Context. In A. Duranti \& C. Goodwin (Eds.), Rethinking Context: Language as an Interactive Phenomenon (pp. 151-189) Cambridge: Cambridge University Press.

Hymes, D. (1972a). On communicative Competence. In J.B. Pride \& J. Holmes (Eds.), Sociolinguistics. Harmondsworth: Penguin.

Hymes, D. (1972b). Models of the Interaction of Language and Social Life. In J.J. Gumperz \& D. Hymes (Eds.), Directions in Sociolinguistics: The Ethnography of Communication (pp. 35-71). New York: Holt, Rinehart \& Winston.

Hymes, D. (1974). Foundations in Sociolinguistics: An Ethnographic Approach. Philadelphia: University of Pennsylvania Press. 
Lave, J. \& Wenger, E. (1991). Situated learning. Legitimate peripheral participation. Cambridge: Cambridge University Press.

Lerner, G. (1993). Collectivities in action: Establishing the relevance of conjoined participation in conversation. Text, 13(2), 213-245.

Ochs, E. (1988). Culture and language development: Language acquisition and language socialization in a Samoan village. Cambridge: Cambridge University Press.

Ochs, E. (1991). Stories that steps into the future. In D.Biber \& E.Flanagan (Eds.) Sociolinguistic perspective on register. Oxford: Oxford University Press.

Pirchio, S. \& Pontecorvo, C. (1997). Strategie discorsive infantili nelle dispute in famiglia. Rassegna di Psicologia, 1, 83-106.

Pontecorvo, C. \& Sterponi, L. (1997). Discourse in family dinner talk: How Italian parents practice to speak as parents. Poster presented at S.R.C.D. (Society for Research in Child Development) Biennial Conference: Washington, D.C.

Pontecorvo, C., Fasulo A. \& Sterponi, L. (in press). Mutual apprenticeship. Adults' and children learning practices in family conversation.

Rogoff, B. \& Lave, J. (Eds.) (1984). Everyday cognition. Cambridge, MA: Harvard University Press.

Sacks, H. (1992). Lectures on conversation. Cambridge, MA: Blackwell.

Sacks, H., Schegloff, E.A. \& Jefferson, G. (1974). A simplest systematic for the organization of turn taking for conversation. Language, 50(4), 696-735.

Schegloff, E. A. (1982). Discourse as an interactional achievement: some uses of 'uh huh' and other things that come between sentences. In D. Tannen (Eds.), Georgetown University Roundtable on Languages and Linguistics (pp. 71-93). Washington, D.C.: Georgetown University Press.

Schegloff, E. A. (1991). Reflections on talk and social structure. In D. Boden and D. Zimmerman (Eds.), Talk and Social Structure: Studies in Ethnomethodology and Conversation Analysis (pp. 44-70). Oxford: Polity.

Schegloff, E. A. (1995). Parties and talking together: Two ways in which numbers are significant Talk-in-Interaction. In ten Have, P. \& Psathas, G. (Eds.), Situated order: Studies in the social organization of talk and embodied activities (31-42). Washington, D.C.: University Press of America.

Schieffelin, B.B. \& Ochs, E. (1986). Language socialization. Ann. Rev. Antropol., 15, 163191.

Sterponi, L. \& Pontecorvo, C. (1996). Discourse at family dinner: how children are socialized through arguing. Interaction et cognitions, 2, 329-365.

Taylor, C. (1995). Child as apprentice-narrator: Socializing voice, face, identity, and self-esteem amid the narrative politics of family dinner. Unpublished doctoral dissertation, Los Angeles: University of California.

Wood, D., Bruner, J. \& Ross, G. (1976). The role of tutoring in problem solving. Journal of Child Psychology and Psychiatry, 17, 89-100. 


\section{Gehören nur zwei Personen zu einer Dyade? Dyadische Konfigurationen in Familiengesprächen mit mehreren Beteiligten}

\section{Zusammenfassung}

Eine Interaktion in Dyaden bedeutet nicht notwendig, dass nur zwei Personen anwesend sind. Oft ist es möglich, Abschnitte in dyadischen Interaktionen aus Kontexten $\mathrm{zu}$ isolieren, an denen mehrere Personen beteiligt sind. Ein Beispiel ist das Gespräch am familiären Mittagstisch, das wir in diesem Beitrag analysiert wird. Bei einem solchen Gesprächsanlass besteht die normale Konversationsstruktur darin, dass in einem unterschiedlich organisierten Rahmen mehrere Personen beteiligt sind. Deshalb braucht es Durchsetzungsvermögen (Goffman, 1964), um Raum und Exklusivität für einen dyadischen Austausch zu gewinnen.

Diese Arbeit zeigt, wie der dyadische Rahmen aus der Interaktionsstruktur mehrerer Beteiligter beim Familienmittag herausgearbeitet wird. Darüber hinaus analysieren wir die Ressourcen, die die Beteiligten einsetzen, um den dyadischen Austausch vor Eingriffen anderer und / oder vor dem Riskiko des Verlassens der Dyade durch ein Mitglied zu schützen. Jüngere und ältere Kinder nehmen aktiv an diesen Handlungen teil und lernen gleichzeitig durch diverse dyadische Situationen solche Aktivitäten zu beherrschen.

Es ist nicht die Anzahl der Beteiligten, die letztlich bestimmt, ob eine Interaktion dyadisch ist oder aus mehreren Mitgliedern besteht. Unterschiedliche und komplexe Beteiligungsrahmen, Allianzen und Herausforderungen werden während des mittäglichen Familiengesprächs gestaltet und verändert; genau in dieser interaktiven Umgebung ständiger Aktivität erfolgt die Sozialisation der Kinder in das komplexe sozio-kognitive Handeln.

\section{Une dyade se compose-t-elle uniquement de deux personnes? Configurations dyadiques dans des conversations familiales avec plusieurs participants}

\section{Résumé}

Une interaction dyadique n'implique pas nécessairement la présence de seulement deux personnes. Il est souvent possible de distinguer des épisodes d'interaction dyadique, telle qu'une conversation familiale à table, faisant intervenir plusieurs personnes. C'est ce que nous analyserons dans le cadre de cet article. Lors d'un tel événement discursif, le cadre de participation des diverses personnes (organisé de façons diverses) est la structure conversationnelle normale. Par conséquent, un gros effort (Goffman, 1964) est exigé des participants pour se positionner spatialement et exclusivement pour un échange dyadique.

Cet article montre comment, lors d'un repas familial, un cadre dyadique peut émerger d'une structure d'interaction faisant intervenir plusieurs personnes. Il 
analyse également les ressources engagées par les participants pour protéger l'échange dyadique d'autres intrusions et/ou du risque de désertion d'un membre de la dyade. Des enfants jeunes et plus âgés participent activement à cette activité et apprennent à la gérer à travers diverses situations dyadiques.

Ce n'est pas le nombre de participants qui détermine univoquement si l'interaction est dyadique ou si elle fait intervenir plusieurs participants. Des structures de participation différentes et complexes, des alliances et des défis sont mis sur pied et transformés tout au long de la conversation qui se déroule lors du repas familial; c'est là le lieu d'une organisation interactive suivie qui permet aux enfants de se socialiser à une activité socio-cognitive complexe

\section{Sono necessarie solo due persone per una diade? Configurazione diadica in dialoghi familiari con più di due partecipanti}

\section{Riassunto}

L'interazione diadica non necessariamente implica la presenza di due persone solamente. E' spesso possibile osservare episodi di interazione diadica in contesti multiparti, quali le conversazioni familiari a tavola, che noi analizziamo. Nell'ottica della struttura conversazionale la partecipazione a situazioni mumtiparti determina negli interagenti la volontà di occupare uno spazio definito per lo scambio con gli altri (Goffman, 1964).

Questo articolo mostra come, nel contesto della cena in famiglia, le risorse dei partecipanti siano indirizzate a proteggere lo scambio diadico dalle intrusioni e/o dal non coinvolgimento di uno dei membri della diade. Bambini grandi e piccoli partecipano a tale attività e apprendono ciò attraverso differenti situazioni diadiche.

Dunque non è il numero dei partecipanti che determina unicamente quando una interazione sia diadica oppure a più partecipanti. Differenti e complesse cornici di partecipazione, alleanze e cambiamenti sono costruite e trasformate nella conversazione familiare a tavola; è questo il luogo dell'organizzazione interattiva di esperienze in cui i bambini apprendono le regole di socializzazione di attività socio-cognitive. 